\title{
Religionenes kunst i klasserom og hellige rom
}

\author{
Teoretiske perspektiver
}

\begin{abstract}
Av Tove Nicolaisen
Møter med religionenes kunst $i$ klasserom og $i$ hellige rom har potensiale til a utvide studenters og elevers loringsrom; komplekse erfaringer kan vare gevinsten. Artikkelen utforsker ulike innfallsvinkler til motene, og hvordan laeringsrommet kan forstås på forskjellige måter. Jeg diskuterer begreper og teorier som kan brukes $i$ undervisning: teorier om rom, om normalitetskonstruksjoner, om tolkning av kunst og om kunstens påvirkningskraft.
\end{abstract}

Nøkkelord: religionenes kunst, hellige rom, hindutempel, moské, ekskursjoner, læringsrom, religions- og livssynsundervisning

Tove Nicolaisen, f. 1946, professor emerita OsloMet, Bertrand Narvesens vei 47, 0661 Oslo, toveni@oslomet.no

\section{INNLEDNING}

Hva skjer når vi møter ulike religioners kunst i klasserom og hellige rom? Hvordan kan lærere og lærerutdannere bidra til reflekterte og analytiske møter med kunst i så forskjellige rom? Det handler denne artikkelen om. Artikkelen har et fagdidaktisk sikte, der målet er å bidra til teoretisk refleksjon om religionenes kunst i religions- og livssynsundervisning. Problemstillingen er: Hvordan kan ulike begreper, teorier og perspektiver være klargjørende og gi kompetanse når studenter og elever møter religionenes kunst $\mathrm{i}$ klasserom og $\mathrm{i}$ hellige rom?

Som lærerutdanner har dette temaet opptatt meg gjennom mange år. Å være på ekskursjon er noe av det jeg har likt aller best, det være seg i Norge, India, Sør-Afrika eller i England (Nicolaisen 2007, 2013, 2014). Jeg har blitt stadig mer interessert i å utforske hva som skjer når læringsrommet utvides og forandres $\mathrm{i}$ møte med religionenes kunst.

Gjeldende læreplan for $\mathrm{KRLE}^{1}$ har flere formuleringer som er relevante med tanke på å utvikle en dynamisk forståelse av religionenes kunst, noe som igjen bidrar til å oppfylle læreplanens mål. Her vil jeg trekke fram at undervisningen skal være objektiv, kritisk og pluralistisk og at kjerneelementer i faget inkluderer mangfoldskompetanse og gjensidig respekt. Elevene skal utvikle evne til å leve i og med mangfold, de skal trenes i å ta andres perspektiver, og de skal lære å forstå religioner og livssyn som sammensatte fenomener.

1 https://www.udir.no/lk20/rle01-03

Prismet - IKO-Forlaget 2021

Tilgjengelig på https://journals.uio.no/index.php/prismet. Publisert under CC BY-NC 4.0. Fagfellevurdert

Årgang 72, hefte 2, s. 119-134 
I artikkelen eksemplifiserer jeg de teoretiske perspektivene ved hjelp av visuell kunst i hinduisme og islam, slik vi finner den i templer og moskeer og bruker den i undervisning. Jeg har valgt templet og hinduguden Ganesh som eksempler fra hinduisme. Ganesh blir satt høyt innenfor så vel den nordindiske som den tamilske tradisjonen i Norge, og han er også en favoritt blant barn. Fra islam bruker jeg moskeen som eksempel.

Mennesker og steder spiller sammen (Soja 2011, 2014). Et hindutempel eller en moské er velkjent for noen, et religiøst hjem, trygghet, et sentralt sted i den tatt-for-gitte livsverdenen, og ofte en forbindelse til opprinnelseslandet. Da vil de visuelle uttrykkene ofte være familiære og trygghetsskapende. For andre kan de samme rommene bli oppfattet som annerledes, merkelige og eksotiske, som «det andre stedet». Ekskursjoner til hellige rom kan gi innsikt og respekt for de andre, men de kan også være mislykket og oppleves som feil fordi en kommer for tett på religiøs praksis og hellig kunst. Det kan føre til avvisning, andregjøring og eksotisering av andres visuelle uttrykk og praksiser (Nicolaisen 2013, 2018). Slik jeg ser det, er bevissthet og kunnskap om kontekst avgjørende for at slike møter skal utvide og berike læringsrommet (Meløe 1970, 1995).

Enkelt sagt er ekskursjon en utflukt med faglig hensikt (Repstad og Tallaksen 2011: 249). På ekskursjon kan en bli kjent med religionenes rituelle, materielle og teologiske sider. Den faglige erfaringen spiller imidlertid ofte sammen med følelsesmessige reaksjoner, både hos dem som opplever det hellige rommet som noe nytt, og hos dem som hører til der. For barn og for voksne studenter kan det være en kilde til stolthet når medelever opplever deres hellige rom, men det kan også oppleves ubehagelig fordi noen synes det de ser, er rart og uforståelig. En jente med hindubakgrunn fortalte etter en ekskursjon til templet at det var både greit og flaut å være der. Det var flaut fordi hun var redd de andre skulle få vite noe om religionen hennes som de syntes var dumt: «Jeg vet at det var noen som syntes det var ekkelt at gudene har så mange armer. Så det syntes de var litt ekkelt da. Også syntes noen det var litt ekkelt at Ganesh har elefanthode» (Nicolaisen 2013:264). Dette viser at møtet med visuelle uttrykk, i dette tilfellet i hinduistisk kontekst, kan føre til andregjøring og eksotisering, mens hensikten var å fremme forståelse og respekt. En ekskursjon bør ideelt sett føre til stolthet og glede for dem som hører til den besøkte tradisjonen.

Det er forsket forholdsvis lite om ekskursjoner i norsk kontekst. Religionsdidaktiker Camilla Stabel Jørgensen (2017) har imidlertid belyst faglig læring og risiko for forkynnelse. Hun diskuterer fritak og representasjon, blant annet med utgangspunkt $i$ standpunktene til religionsdidaktikerne Bengt-Ove Andreassen og Levi Geir Eidhamar. Jørgensens empiri er studentlogger fra ekskursjoner i Trondheimsområdet. Hun er positiv til ekskursjoner i religions- og livssynsfaget og mener at det å kvalifisere studenter og elever «til å ta selvstendig 
stilling til både religiøse og sekulære uttrykk, formidlet visuelt, gjennom tekst og/eller tale, er en del av formålet med faget» (s. 161). Dette slutter jeg meg til. I denne artikkelen skal jeg imidlertid ikke diskutere ekskursjoner generelt, men fokusere på møter med den hellige kunsten. I norsk kontekst er det særlig Geir Winje $(2002,2012,2013)$ som har vært opptatt av å formidle kunnskap om religionenes visuelle kunst.

Jeg presenterer i artikkelen teorier og begreper som kan brukes til å utforske ulike perspektiver på kunst i hellige rom og i klasserom. Disse anvender jeg på undervisningsopplegg knyttet til ekskursjoner og til undervisning om hinduisme og islam. Til slutt peker jeg på noen utfordringer for religions- og livssynsundervisning.

Teoriene som blir presentert og anvendt på undervisningsopplegg er, i tillegg til Winje, konseptet visuell kultur (Seland 2010), Meløes (1970, 1995) begrep erfaringstenkning, Sojas $(2011,2014)$ teori om rom, Foucaults (1967) begrep heterotopia, Gells (2013) teori om kunst, samt dimensjonsmodellen Breidlid og jeg $(2007,2011)$ utviklet til fortellingsdidaktikken, dessuten analyser om dominerende diskurser og normalitetskonstruksjoner i religionsundervisning fra mitt doktorgradsarbeid (Nicolaisen 2013).

Undervisningsoppleggene som jeg bruker, er om Ganesh og om hindutempel og moské. Opplegget om Ganesh gjennomførte jeg som starten på undervisningen om hinduisme. Jeg sendte «forestillingen Ganesh» på en reise fra høgskole til tempel, for sammen med studentene å utforske hva som skjer når en gud forflytter seg mellom kontekster. Jeg satte fram en ganesh-figur (bilde 1, se neste side) i undervisningsrommet, ba studentene beskrive den og diskutere de ulike kjennetegnene. I templet fikk studentene erfare tilbedelsen av en ganesh-murti (bilde 2, s 123), og de fikk oppgaver som skulle besvares skriftlig også her, med spørsmål om kontekst og kontekstens innflytelse. Dessuten anvender jeg teorier og begreper på hindutempel og moské, knyttet til ekskursjoner. Vi besøkte hindutempler på tidspunkt da det ble utført ritualer som puja og aarti, slik at studentene fikk erfare religiøs praksis og den visuelle kunsten i en tilbedelseskontekst. Noen av ekskursjonene til moskeer foregikk i forbindelse med fredagsbønn. Ved andre ekskursjoner var det mer tilfeldig om studentene fikk erfare folk som ba. Før ekskursjonene var det undervisning om kunsten, rommene og ritualene; etter besøkene samtaler om erfaringene som ble gjort. Noen ganger var det hinduer og / eller muslimer i klassene. Studentene skrev tekster, og jeg viser i artikkelen til utsagn som er typiske og som kan være opplysende.

\section{TilnÆRMINGER TIL DET ROMLIGE}

Kunsthistoriker Eli Seland (2010) bruker begrepet visuell kultur. Det handler om å se, og om de sosiale og historiske kontekster og praksiser bilder er en del av. Et 
bilde kan forflytte seg mellom visuelle kulturer, og bildets mening vil forandre seg når konteksten endres. Tilnærmingen tar på alvor at vi lever i en tid der visuelle uttrykk krysser grenser og forstås på nye måter. ${ }^{2}$ Uttrykkene viser seg på mangfoldige måter og skifter fra etablerte til stadig nye former og meningsinnhold, som når en buddha-figur blir interiørartefakt. Det trengs kompetanse til å nyttiggjøre seg betydningen av møter mellom mening og kontekst. Seland skiller mellom det fysiske bildet og den ideen det uttrykker. Bilder og statuer av hinduguder har sitt utspring i en religiøs kontekst, som noen elever vil være godt kjent med. For dem kan hinduguder i skolekonteksten være en ny opplevelse. For ikke-hinduer kan tempelkonteksten være ny.

Selands teori om visuell kultur bruker jeg på erfaringer med det nevnte undervisningsopplegget der Ganesh «er på reise» fra klasserom til tempel. To av oppgavene studentene fikk i forbindelse med tilbedelsen av Ganesh-murtien, var:

1 Beskriv Ganesh-statuen og konteksten den står i. Skjedde det noe med din forståelse av Ganesh sammenlignet med den forståelsen du hadde på forhånd? Eventuelt hva? Hva er forskjellen på å oppleve Ganesh i klasserommet og i templet?

2 Beskriv det du så i tempelrommet. Hva forteller tempelrommet om hindutradisjonen?

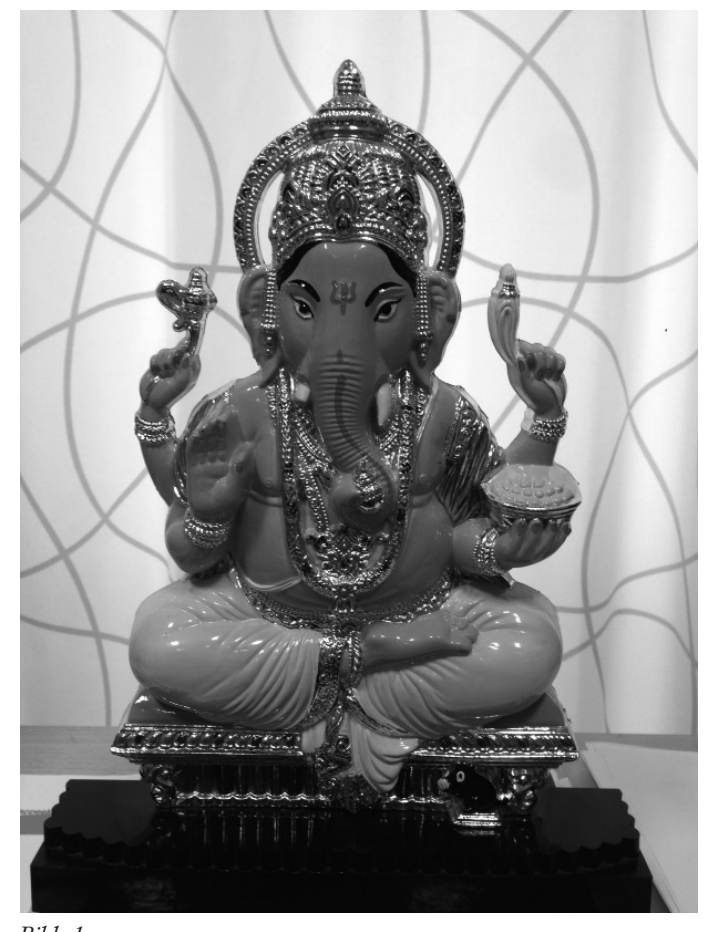

Bilde 1
Oppgavene ble brukt i oppsummeringen av ekskursjonene. Noen studenter var helt klare på at de hadde fått en utvidet forståelse av hindutemplet og av Ganesh, ved å bruke beskrivelser som at Ganesh-statuen var opphøyd i templet og at opplevelsen ble annerledes i templet enn i klasserommet fordi konteksten var en annen. Noen la vekt på at i templet var alle sansene i bruk og at besøket ga dypere innsikt og førte til aksept. Når et bilde flytter mellom rom, kan dets idé være krevende å forstå,

2 Denne endringen i betydning gjelder også lyduttrykk og fortellinger, noe som ikke er tema her. 
men når en representasjon, som Ganesh, oppleves og snakkes om i et fellesskap av hinduer og andre, vil alle få mulighet til å se Ganesh med nye øyne. Slik kan en ekskursjon føre til nytenking.

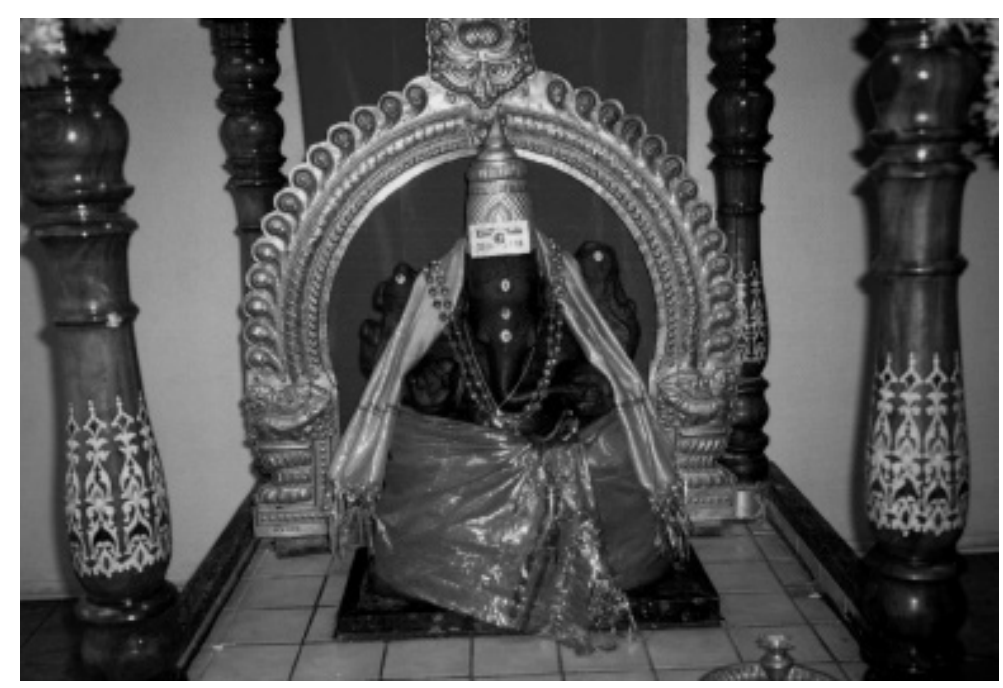

Bilde 2

Et godt utbytte av møtet med kunst i klasserom og i hellige rom handler om å bli bevisst betydningen av kontekst. Filosof Jakob Meløe $(1970,1995)$ er opptatt av aktøren og hans/hennes verden. Erfaringstenkning er når vi forstår hvorfor aktører handler som de gjør i en kontekst, det vil si at vi blir kjent med noe av den andres verden. Meløe bruker eksempler fra dagligliv i Nord-Norge, men det kan også anvendes på erfaringer knyttet til ekskursjoner. Det kan handle om hvorfor hinduer legger blomster og frukt foran gudestatuene. Eller om hvorfor presten sirkulerer en oljelampe foran dem. Det kan handle om hvorfor det er viktig å resitere korantekster eller om bønnestillinger. Erfaringstenkning er en nøkkel til forståelse.

Ekskursjoner utvider læringsrommet når elever erfarer at de forstår levende og materiell religion bedre. Da har de forstått noe av andres perspektiver. Det kan også føre til et møte med egne holdninger og fordommer; egne perspektiver blir satt under lupen. Ekskursjoner kan knyttes til gjenstander, som en ganeshstatue, et eksemplar av Koranen, et bønneteppe, en buddhastatue, en menora, et kors, en framstilling av khanda. Andre muligheter er å knytte forberedelser og etterarbeid til sentrale begreper som darshan, murti og puja i hinduisme og tanzil, qibla og salah i islam - og tilsvarende i andre tradisjoner. Gjenstander og begreper blir knagger for forståelse av så vel kunst som praksis. Erfaringstenkning skjer når elever oppdager hvorfor de som praktiserer en religion, handler som de gjør i et 
hellig rom i samspill med ulike artefakter.

Til forstålsen av sted vil jeg rekke fram samfunnsgeograf Edward Sojas (2011, 2014) teorier. Han er opptatt av hvordan vi forstår rommene rundt oss. Rom eller sted (space) ${ }^{3}$ har ifølge Soja tre dimensjoner. Det første rommet (first space) betegner materielle kvaliteter som muliggjør og begrenser ulike handlinger og praksiser. Det andre rommet (second space) handler om forestillinger vi har om steder. Forestillingene kan være intellektuelle, politiske, populære eller religiøse. De kan være idealiserende, men også andregjørende og eksotiserende. Dermed kan et sted framstå som heterotopia (Foucault 1967), annerledesstedet, som må forstås med utgangspunkt $i$ at de fleste av oss opplever noe som normalt og tatt for gitt - og dermed noe annet som «det andre».

Sojas første og andre rom kan sammenlignes med Selands skille mellom det fysiske bildet og den ideen det uttrykker. Forestillinger skaper forståelse av steder og er avgjørende når et sted defineres. Slik oppstår også forestillinger om steders kvaliteter og betydninger. First space er en realistisk forståelse av sted, mens second space er en idealistisk forståelse. Det interessante er at Soja også opererer med et tredje rom (third space). Det tredje rommet søker å oppløse motsetningen mellom det materielle og forestillinger, mellom realisme og sosialkonstruktivisme, ved å forstå sted som både «real-and-imagined». Soja er inspirert av Homi Bhabha (2008), et av de store navnene innenfor postkolonial teori, og hans teorier om det tredje rommet. Soja (2011:57-58) beskriver det tredje rommet slik:

Alt sammenfoyes i det tredje rommet: subjektivitet og objektivitet, det abstrakte og det konkrete, det virkelige og det forestilte, det gjenkjennelige og det som vi ikke kan forestille oss, det som gjentar seg og det som skiller seg ut, bevissthet og det ubevisste, det disiplinerte og det som går på tvers, hverdagsliv og endelos historie. Alt som deler opp det tredje rommet $i$ atskilte spesialiserte eksklusivistiske kunnskapsområder - selv når hensikten er å hanskes med uendelig kompleksitet - ødelegger det tredje roms mening og åpenhet (min oversettelse).

Dette er en multiperspektivistisk tilnærming til rom, der det handler om å bevege seg forbi det som er kjent, for eksempel ved å få en tredjeroms-erfaring av Ganesh, det vil si den materielle siden ved en representasjon av Ganesh, Ganesh som forestilling og den tilbedte Ganesh i møtet mellom akademisk kunnskap, klasserom, tempel og religiøs praksis. Eller en tredjeroms-erfaring av templet. Min erfaring er at mange studenter kom nærmest en slik forståelse når de beskrev

3 Det har i mye litteratur om rom vært vanlig å skille mellom begrepene «space» og «place». Det var Ty-Fu Tuan som i 1977 introduserte denne typologien (Rogan 2011:322, Tuan 1977). Tuan mener at mennesker tilegner seg «the abstract unlimited space» ved å transformere den til «concrete places». «Place» handler om trygghet, mens «space» handler om frihet - kort fortalt. Til mitt formål har Sojas teorier vært nyttigere å bruke. 
og samtalte om moskerommet. Mange la vekt på hvordan interiøret og utsmykningen av rommet gjenspeiler sentrale ideer, kultur og historie i islam. Elementer som ble trukket fram var sammenhengen mellom utsmykning og bønn, fellesskap og troen på én gud. Altså stedets fysiske utforming og teologien. Jeg kommer tilbake til den utfordringen det er at noen studenter ser ut til å forstå moskeen bedre enn templet.

Filosof Michel Foucault (1967) har, som allerede nevnt, pekt på heterotopia, forstått som det andre stedet, «counter-sites, outside of all places, even though their location can be indicated in reality» (s. 3). Heterotopier er marginale steder i den moderne verden og står i kontrast til utopia, idealiserte steder. For dem som hører til et hellig sted, vil det kunne forstås som en gjenspeiling av den guddommelige virkeligheten, det vil si et perfekt sted. Mens utenforstående kan se det som et annerledes, marginalt og uforståelig sted. Noen av tekstene studentene skrev om templet, uttrykte forvirring, mangel på forståelse og ny kunnskap; de hadde overfladiske beskrivelser av templet og gudsbegrepet. Perspektivene i tekstene kan derfor kalles heterotopiske. Det nye de opplevde, virket forvirrende og fremmedgjørende. Det kunne handle om at tempelbesøket ga inntrykk av at hinduisme har mange guder og at det er vanskelig å vite hvem som er hvem av gudene.

Soja (2014) legger vekt på at Foucaults konsept heterotopia må forstås som et perspektiv på alle typer rom, noe jeg er enig i. Ofte vil det være slik at undervisningen presenterer utopia, og at noen studenter erfarer heterotopia. Ved første øyekast kan det ses som negativt at studenter har heterotopiske erfaringer, men vi kan velge å se annerledes på det og spørre om ikke slike erfaringer kan være virkningsfulle startpunkt for ny læring.

Foucaults begrep heterotopia kan hjelpe oss til å forstå hvorfor noe oppleves som annerledes, rart eller eksotisk. Et nyttig - og nødvendig - grep er å trene elever til å se forskjellen på det vi tar for gitt som naturlig og normalt, i motsetning til det vi synes er annerledes og rart. Og selvfølgelig at for andre vil dette ofte være helt annerledes. I norsk religions- og livssynsundervisning har et tradisjonelt vestlig syn på religion vært tatt for gitt, og andre forståelser kan dermed bli andregjort (Nicolaisen 2012, 2013). Dette kommer jeg tilbake til.

\section{TILNÆRMINGER TIL VISUELL KUNST}

I undervisning kan en bruke visuell kunst på ulike måter. Her skal jeg kort ta for meg to tilnærminger og gå grundigere inn på en tredje. Alle metodene kan anvendes så vel i klasserom som i forbindelse med ekskursjon.

For det første kan visuelle uttrykk analyseres og tolkes som tekst. ${ }^{4}$ Geir Winje

4 Rogan (2011: 326-333) viser hvordan denne forståelsen i vår tid har sitt utgangspunkt i strukturalismen. Ting blir sett som elementer i en kommunikasjonsprosess, der de formidler abstrakte ideer. Kultur er altså kommunikasjon. Tingen er et tegn og et symbolsk uttrykk. 
(2003, 2012, 2013) argumenterer for en slik tilnærming. Hans utgangspunkt er at bildekunst bør ses som selvstendige meningsbærende uttrykk, i motsetning til å se bilder som illustrasjon til en skriftlig tekst. Før boktrykkerkunsten var det vanlig å bruke kunst på denne måten. Analyse av bilder kan være å jobbe med motiv, formale virkemidler og budskap. Gjelder det en ganesh-figur, kan en starte med å beskrive og tolke selve figuren og de ulike attributtene, sette det inn i kontekst og ut fra det utforske budskapet.

Halldis Breidlid og jeg (2011, kap. 3) ${ }^{5}$ introduserte en tolkingsmodell der religionenes fortellinger har tre dimensjoner. den allmennmenneskelige, den religionsspesifikke og den religiøse dimensjonen. Visuelle uttrykk kan tolkes på samme måte (Winje 2003, Rolland 2016, Nicolaisen 2018). Denne modellen erkjenner at kunst erfares ulikt av den enkelte. Lars Rolland viser i sin masteroppgave hvordan et bilde av Radha og Krishna kan forstås ved hjelp av dimensjonene. Også en Ganeshfigur kan tolkes ut fra en tilnærming i det allmennmenneskelige, det spesifikt hinduistiske og det felles religiøse.

Den tredje tilnærmingen karakteriserer kunst som agent, det vil si som en påvirker som får noe til å skje. Dette er spesielt interessant anvendt på møtet mellom studenter/elever og kunst i hellige rom. Hovedpoenget i antropolog Alfred Gells (2013) teori er at materiell kunst er et møtepunkt mellom ulike aktører. I visse kontekster kan personer bli erstattet av kunstobjekter (s. 5). Gell argumenterer mot å se kunst som tekst:

In place of symbolic communication, I place all the emphasis on agency, intention, causation, result, and transformation. I view art as a system of action, intended to change the world rather than encode symbolic propositions about it. The 'action'-centred approach to art is inherently more anthropological than the alternative semiotic approach because it is preoccupied with the practical mediatory role of objects in the social process, rather than the interpretation of objects 'as if' they were texts ( $p .6)$.

Gell mener at visuelle uttrykk kan være en part i sosiale relasjoner og at de derfor har agentskap. Agentskapet er relasjonelt og avhengig av kontekst (s. 22). Nora Stene (2011) brukte Gell for å tydeliggjøre koptiske barns forhold til hellige bilder. Sentralt i teorien er de dynamiske relasjonene mellom ulike agenter (s. 12-27). I figuren nedenfor presenterer jeg en forenklet framstilling av noen av Gells begreper. Begrepene er i venstre kolonne, forklaringer i midtre, og til høyre anvender jeg dem på undervisning om Ganesh.

I Gells teori vil Ganesh ha agentskap, det vil si påvirkningsmakt. Relasjonen mellom en ganesh-murti og betrakteren får karakter av å være sosial utveksling. Murtien blir en agent fordi den befinner seg i en kontekst som inkluderer den

5 Første utgave 2000 


\begin{tabular}{|c|c|c|}
\hline $\begin{array}{l}\text { Gells } \\
\text { begreper }\end{array}$ & Forklaringer & Ganesh i tempelkonteksten \\
\hline The index & $\begin{array}{l}\text { Den synlige materielle, identifiserbare gjenstan- } \\
\text { den }\end{array}$ & $\begin{array}{l}\text { Ganesh-murti (en innviet statue av } \\
\text { Ganesh) i templet }\end{array}$ \\
\hline The artist & $\begin{array}{l}\text { Kunstneren / håndverkeren / et kollektiv som } \\
\text { lager gjenstander til bruk i tilbedelse }\end{array}$ & $\begin{array}{c}\text { Den / de som har laget den spesifikke } \\
\text { murtien }\end{array}$ \\
\hline The prototype & $\begin{array}{c}\text { Modellen / motivet / den eller det som indeksen } \\
\text { representerer }\end{array}$ & $\begin{array}{l}\text { Guds tilstedeværelse i tid og rom / Guds } \\
\text { nedstiging i murtien (arcavatara) }\end{array}$ \\
\hline The recipient & $\begin{array}{l}\text { De som mottar indeksens påvirkning og samhan- } \\
\text { dler med den }\end{array}$ & $\begin{array}{l}\text { Tilbedere og / eller observerende stu- } \\
\text { denter og elever på ekskursjon }\end{array}$ \\
\hline
\end{tabular}

som har laget den, prototypen (Gud) og en mottaker, som kan være en observerende student eller en tilbeder. Murtiens agentskap er imidlertid avhengig av mottakerens kunnskap om og erfaring av konteksten, i dette tilfellet tempel, praksis og gudsbegrep. Et bilde er altså ikke en aktør i seg selv, men i konteksten framtrer det som personlikt og får virkningskraft (Gell 2013:16-17). Betingelsen for at bildet skal virke, er at den som ser bildet, allerede er kjent med konteksten (Gell 2013: 256).

Studenters erfaringer fra hindutempel kunne være ambivalente. De kunne uttrykke fascinasjon og opplevelse av noe som var helt annerledes, samtidig som de erfarte «mer hellighet» og at Ganesh var «mer verdt» enn de hadde tenkt. Altså en samtidig erfaring av murtiens agentskap og av noe som var heterotopisk. Denne erfaringstenkningen om tilbederens verden kan være en inngang til det tredje rommet.

Elever og studenter trenger verktøy for å kunne utforske og tolke religionenes kunst, verktøy som kan brukes til å oppøve bevissthet om mangfoldet av visuelle uttrykk og hvordan bilder og andre uttrykk forandrer seg når kontekster skifter. Det er mulig at det å tolke kunst som tekst, kan karakteriseres som utenfraperspektiv, mens Gells teori om agency, kan nærme seg et innenfraperspektiv. Men alt henger sammen med den enkeltes ståsted. Når det gjelder dimensjonsmodellen, kan den allmennmenneskelige og den religiøse dimensjonen ha noe av agentperspektivet, mens den religionsspesifikke dimensjonen kan ha noe av tekstperspektivet, men dette er igjen avhengig av eget ståsted og bakgrunn. Det kan høres ambisiøst ut, men jeg er overbevist om at det er mulig - og nødvendig - å trene både studenter og grunnskoleelever i å diskutere metaperspektiver på egne erfaringer med religionenes kunst. 


\section{OM A FORSTA TEMPEL OG MOSKÉ}

Jeg har erfart at studenter ofte forsto moskeen bedre enn de forsto hindutemplet. Jeg skal derfor gå nærmere inn på disse og utfordringer knyttet til undervisningen. Studentene fikk oppgaver knyttet til besøk i tempel og moské. I oppsummeringen la mange vekt på at ekskursjonene til moské ga dem ny og utvidet forståelse, men også gjenkjennelse med basis i undervisningen, en erfaring av hvordan det virkelig er i en moské. Dessuten var mange opptatt av hvordan rommet gjenspeiler sentrale elementer i islam, som bønn, fellesskap og renhet. Når det gjaldt studenters møte med hindutemplet, var erfaringene langt mer blandet.

\section{Hindutemplet}

Hindutemplet ses som Guds bolig, et møtested mellom Gud og mennesker; mennesker går i templet for å tilbe Gud og få darshan, det guddommelige blikket, den guddommelige kraften som omslutter den tilbedende (Eck 1998, Nicolaisen 2018). Tilber du ved en murti, en innviet statue, befinner du deg i kraftfeltet til Guds makt. Å gjøre puja gir god karma og kan fjerne dårlig karma.

Hindutemplet kan forstås utfra ulike teoretiske perspektiver. Først Soja. Et konkret tempel, som Sanatan Mandir Sabha på Slemmestad eller Sivasubramanyar Alayam på Ammerud i Oslo er materielle rom og kan beskrives via konkreter som murtier, aarti-lamper, beholdere med vann osv. Men hindutemplet er også en forestilling, som kan oppleves som trygt, som et religiøst hjem og som gudenes bolig, et møtested. I diaspora kan det være et sosialt sted der en tar vare på opprinnelseslandets språk og kultur. Hindutemplet som sådan er altså en forestilling, og det kan også spesifikke templer være. I indisk tenkning er det slik at et helligsted kan gjentas på nye steder. Har du ikke anledning til å besøke et konkret helligsted i Varanasi, kan du besøke duplikater andre steder i India (Jacobsen 2010:205-207). Dette er eksempel på hvordan et spesifikt og konkret helligsted er en forestilling som materialiserer seg på nye steder. Slik kan også hellige steder dannes i Norge, som Vesletjern i Oslo, som er blitt en tirtha, et hellig møtested, der hinduer utfører ritualer (Nicolaisen 2018:85). Kombinasjonen av det konkrete og forestillingen skaper et tredje rom.

Så Foucault. For en utenforstående kan templet framstå som heterotopia, som et eksotisk, fremmed og merkelig sted, som avvik fra «vanlige gudshus», som tas for gitt og oppfattes som normale. Templet avviker selvfølgelig fra klasserommet. Erfaringene til dem som bruker templet henger sammen med templet som konkret forestilling, og kan være et sted for tilhørighet. For den utenforstående vil det være et sted å besøke; det kan være en reise inn i noe fremmed. I religionsundervisning, sett som et tredje rom, virker alt dette sammen, og kan bli diffust, mangetydig og uklart; og konkret, virkelig og en forestilling, hjemlig og fremmed.

Hvordan ser templet ut fra perspektivene til Meløe og Gell? Studenter ga 
uttrykk for at når de så ritualer utført for ganesh-murtien i templet, forsto de mer. Slik ble det tydelig at klasserommet og tempelrommet er ulike settinger og at erfaringen av Ganesh avhenger av konteksten. De kunne beskrive både hva de observerte og følte når de så tilbedelse. Uttrykk som gikk igjen var «oppleve», «erfare», «mer virkelig» og «være en del av», noe som kan tyde på at det kan ha foregått en form for utveksling. Murtien av Ganesh befant seg i krysningspunktet mellom de ulike aktørene: studenten, tilbederen, Guds tilstedeværelse og også indirekte kunstneren/håndverkeren som hadde laget murtien. Dette perspektivet kan representere så vel Gells agentskap, som Meløes erfaringstenkning. Den materielle Ganesh og ideen Ganesh smelter sammen. Mange brukte ordet «mer». Ekskursjonen har ført til en forståelse av Ganesh som mer hellig, tempelkonteksten som mer rituell, opplevelsen av å være i templet som mer høytidelig. Dette tyder på bevissthet om betydningen av at kontekst skifter og evne til å inkorporere gammel kunnskap i nye erfaringer. Samtidig som mange uttrykte at de forsto mer, var det også noen som sa at de var forvirret og skjønte mindre. Dette i motsetning til forståelsen av moskeen.

\section{Moskeen}

Mens hindutemplet blir regnet som Guds bolig, er moskeen et sted for tilbedelse av Gud gjennom bønn, koranresitasjon, kalligrafi og fellesskap. Bønnen, salah, er sentral. I islamsk teologi er Gud transcendent, men på samme tid er tanzil, nedsendingen av Koranen i sentrum. En tilbeder kan derfor erfare Guds ords nærvær som resitasjon og som kalligrafi.

Religionsviter Jan Opsal $(2011 \mathrm{a} / \mathrm{b})$ beskriver tre moskeer i Oslo utvendig og innvendig, Central Mosque of World Islamic Mission, Central Jamaat-e Ahl-e Sunnat og Islamic Cultural Centre. Opsals artikler bygger blant annet på besøk i Oslos moskeer, med og uten studenter. Han peker på tre sentrale retninger i moskeen. Qibla er bønneretningen som peker utover; transcendens peker oppover i retning Gud; retningen bortover peker mot fellesskapet, rekken av de bedende. Kanskje også retningen nedover burde være med. Begrepet tanzil betegner nedsendingen av den åpenbarte Koranen (Eggen 2007, 2011:91). Dermed kan begrepene qibla, salah, transcendens og tanzil karakterisere moskeer.

Med Soja kan vi si at konkreter som bønnenisje, bønnetepper, kalligrafi og Koranen som tilstedeværende bok representerer first space, mens forestillingen moské, forestillingen om Guds transcendens og tanzil kan representere second space. Jeg erfarte ikke at studenter uttrykte heterotopiske holdninger om moskerommet. $^{6}$

Hva med erfaringstenkning og agentskap? Det var mange positive utsagn om moskeen. Beskrivelsene legger vekt på renhet, lys og skjønnhet, og dette ble sett i

6 Studenter kunne imidlertid uttrykke heterotopiske holdninger til ting som ble sagt i moskeen. 
sammenheng med sentrale ideer i islam, som retning, nærhet til andre, fellesskap, fred og Koranens betydning. Det kan tolkes som en forståelse av rommets agentskap. Rommet uttrykker grunnleggende elementer i religionen. Dette kan også sies om hindutemplet, men noen studenter så ut til å forstå dette dårligere.

\section{Konsekvenser for undervisningen}

Spørsmålet blir hvorfor studenter kunne vise god forståelse for moskeen, mens det kunne være mer utfordrende med hindutemplet. Hvilke konsekvenser bør slike holdninger få for undervisningen? Det er nærliggende å tenke at for noen oppfattes moskeen som mer lik tidligere erfaringer fra rom i kristne tradisjoner. De kan trekke på likhetene mellom de tre midtøsten-religionene og på det som oppfattes som «vanlige» hellige rom. Dette er imidlertid en del av et større bilde, som handler om ståsted og om koloniserende diskurser i religionsundervisningen (Nicolaisen 2012, 2013, 2018).

I mitt doktorgradsarbeid, som handler om barn med hindubakgrunn og deres erfaringer med religions- og livssynsundervisningen i norsk skole, analyserte jeg normalitetskonstruksjoner og eksotisering i undervisningen (2013:169-244). Religionsundervisningen i norsk skole har tradisjonelt lagt opp til en presentasjon av religionene som i hovedsak er basert på luthersk kristendomsforståelse, med vekt på religion som tro, et skille mellom tro og praksis, og på klart atskilte religioner og livssyn. Dessuten kan presentasjonen av gudsforståelser være sterkt forenklet. Disse normalitetskonstruksjonene passer bedre til noen tradisjoner enn til andre. Mitt poeng var å vise at hinduers religionsforståelser og gudsforståelser kunne være annerledes enn den normaliserte forståelsen i planer, læreverk og undervisning. Dermed kunne gudsbegrepet og estetikken i hinduisme være vanskeligere å forstå, sett fra et «kristent-kulturelt» ståsted. Mens det for hinduer selvfølgelig kunne fortone seg motsatt. Et eksempel på det er at hindubarn i min undersøkelse syntes det var vanskelig å forholde seg til framstillinger av korsfestelsen i kristendom med en gud som var «spikra» til et kors (2013:225-226). Dermed er vi tilbake i kontrasten mellom det som tas for gitt og det som oppleves annerledes. Slik jeg ser det, er det her religions- og livssynsundervisningen må ta et krafttak for å oppnå forandring som fører til aksept av mangfold.

Skal elever med mangfoldige bakgrunner forstå hellige rom og religionenes visuelle kunst, er det behov for verktøy som fremmer perspektivskifter og utvider læringsrommet. Særs viktig er det å jobbe med spørsmålet om normalitet for å vise at det finnes utallige versjoner av hva som oppfattes som vanlig og normalt. Dette må gjøres både teoretisk og i praksis. En praktisk øvelse kan for eksempel være rollespill. Jeg vil framheve det KRLE-planen sier om å ta andres perspektiver. Det kan handle om å avdekke og avkolonisere normalitetskonstruksjoner. Nyttig verktøy i den forbindelse kan være de tilnærmingene til religionenes kunst 
som jeg har diskutert i denne artikkelen.

Barn med hindubakgrunn kunne erfare at andre ikke viste respekt for deres gudsforestillinger og visuelle kunst, mens de selv la vekt på å respektere andre. Jeg fant (2013) at hinduer kunne oppleve andregiøring i undervisningen, at hinduisme kunne presenteres som «den andre» i kontrast til normalitetskonstruksjoner om religion. Hindubarna kunne bli konfrontert med en normalitet om religion som på flere områder avvek fra deres livsverden. Likevel lyktes de i å bidra konstruktivt i undervisningen. De hadde selvstendige meninger og holdninger, som de var stolte av (s. 278). Jeg kalte dette egengjøring, et begrep jeg konstruerte for å sette ord på barnas selvforståelser og posisjoneringer. Det å forstå andres posisjoneringer - eller perspektiver - er et skritt i retning mot avkolonisering av hegemoniske diskurser.

\section{KONKLUSJON}

Hensikten med artikkelen var å utforske hvordan ulike begreper, teorier og perspektiver kan være klargjørende og gi kompetanse når studenter og elever møter religionenes kunst i klasserom og i hellige rom, ment som et bidrag til å utvikle mangfoldskompetanse, gjensidig respekt og evne til å forstå andres perspektiver. Lærere, studenter og elever trenger kunnskaper som kan gi metaperspektiver på faglige erfaringer og følelsesmessige reaksjoner i møte med religionenes kunst $\mathrm{i}$ klasserom og i hellige rom. For noe skjer når vi møter kunst som kan påvirke oss på så vel opplysende som negative og fremmedgjørende måter. På sitt beste bidrar møter med kunst $\mathrm{i}$ hellige rom til at elever erfarer betydningen av å praktisere en religion, at de utvikler forståelse for andres perspektiver og at de får trening i å forholde seg til ulike former for påvirkning og annerledeshet.

Elever og studenter må trenes i å forholde seg til kunstens påvirkningskraft. Jeg har valgt ikke å fokusere spesifikt på forkynning/påvirkning og fritak i denne artikkelen. Jeg anbefaler Jørgensens artikkel (2017), der dette diskuteres grundig. Påvirkning vil imidlertid alltid være til stede, og elever trenger kompetanse for å forstå og forholde seg til mange typer påvirkning. Menneskers grenser er individuelle og mangfoldige; dette gjelder så vel barn som foreldre og lærere. Derfor er det vanskelig å trekke allmenngyldige grenser. Et mulig grep i undervisning er å jobbe med samspillet mellom steder og mennesker, for mennesker blir påvirket av steder, og steder blir preget av dem som er der. Dette kan prøves ut i praksis, analyseres og diskuteres. Elever må selv etter hvert utvikle bevissthet om hvor de skal trekke grenser, i samspill med medelever og kloke voksne, og med hjelp fra kunstfaglig og religionsfaglig verktøy.

I artikkelen valgte jeg å bruke eksempler fra hinduisme og islam, fordi det er behov for mer kunnskap om disse tradisjonene; hinduisme fordi den i norsk kontekst ofte blir oversett eller eksotisert (Nicolaisen 2013), islam på grunn av 
misforståelser og utbredt islamofobi. En del forestillinger om disse tradisjonene må derfor avkoloniseres. For eksempel kan framstillinger av Ganesh bli utsatt for eksotisering, fordi de kan utfordre forestillinger noen har om hvordan en gud bør representeres. Slik jeg ser det, må en pluralistisk undervisning avdekke ulike virkelighetskonstruksjoner og forstå hva som skjer når religionenes bilder, lyduttrykk og fortellinger framtrer i ulike rom. Slik kan en minimalisere andregjøring og fremme egengjøring.

Bhabhas (2008) teorier om det tredje rommet har hatt stor betydning for min forståelse av mulighetene i flerkulturell undervisning. Slik jeg ser det, handler læringsrommet som et tredje rom om noe overskridende. Det handler om innovative måter å samhandle, tenke og samtale på. Det handler om å avsløre og dekonstruere normalitetskonstruksjoner og om å bli opplyst av ulike perspektiver som ses i sammenheng, av utforskende dialog og gjestfrihet. Slik utvides læringsrommet. Det tredje rommet åpner for en gjestfri, generøs og respektfull innstilling til andre.

Møtet med kunst i hellige rom kan være en reise som starter i den tatt-for-gitte livsverdenen og fører inn i det fremmede. Du forlater skolen og kommer til et nytt sted for å få kunnskap du ikke kan få i klasserommet. Du drar på ekskursjon fordi du trenger dette spesifikke stedet for å erfare noe annerledes og viktig. Den samme reisen kan for andre handle om å komme hjem. Men i begge tilfeller må vi innse at resultatet kan være uforutsigbart, noe som vel gjelder undervisning i sin alminnelighet. Læringsrommet kan være et uklart og ambivalent sted, men det kan utforskes ved hjelp av begreper, teorier og kunstuttrykk.

\section{LitTERATUR}

Bhabha, Homi K. (2004) / 2008. The Location of Culture. New York: Routledge. Breidlid, Halldis og Tove Nicolaisen. 2007. På skattejakt $i$ fortellingsuniverset. Fortelling i religionene. Bergen: Fagbokforlaget.

Breidlid, Halldis og Tove Nicolaisen. 2011 (2000). I begynnelsen var fortellingen.

Oslo: Universitetsforlaget.

Eck, Diana L. 1996. Darsan. Seeing the Divine Image in India. New York: Columbia University Press.

Eggen, Nora S. 2007. Koranen. Innfering i en tekst- og tolkningstradisjon. Oslo: Solum forlag.

Eggen, Nora S. «Koranen - islams hellige skrift». I Hellige skrifter i verdensreligionene, red. Braarvig og Justnes, 87-119. Kristiansand: Høyskoleforlaget.

Foucault, Michel. 1967. Of Other Spaces. Heterotopias. Tilgjengelig: http:// foucault.info/documents/heteroTopia/foucault.heteroTopia.en.html (hentet 08.03.20) 
Gell, Alfred. (1998) / 2013. Art and Agency. An Anthropological Theory. Oxford: Clarendon Press.

Jacobsen, Knut A. 2010. Hinduismen. Oslo: Pax.

Jørgensen, Camilla Stabel. 2017. «Bør ekskursjoner være del av religions- og livssynsundervisningen?» I Religion i skolen. Didaktiske perspektiver på religionsog livssynsfaget, red. Lippe og Undheim, 144-164. Oslo: Universitetsforlaget.

Laereplan for KRLE: https://www.udir.no/lk20/rle01-03 (hentet 07.03.20)

Meløe, Jacob. 1970. "Aktøren og hans verden». I Philosophia Arhuensis. 2/70: 17-27. Århus: Filosofisk forening.

Meløe, Jacob. 1995. «Steder». I Hammarn 3/95: 6-12. Tromsø: Nordnorsk kulturråd.

Nicolaisen, Tove. 2007. «Pluralitet, planer og praksis. Mangfold i klasserommet når KRL står på timeplanen. Perspektiver på aksjonsforskning og livssynspluralitet i en grunnskole i Oslo». I Prismet 1/58: 221-235. Oslo: IKO.

Nicolaisen, Tove. 2012. «Corresponding Values and Colonising Discourses. Situating "Hindu Children" and their Values in relation to Hegemonic Norwegian Discourses about Religious Education». British Journal of Religious Education 34 (3): 231-245. DOI:10.1080/01416200.2011.628193

Nicolaisen, Tove. 2013. Hindubarn i grunnskolens religions- og livssynsundervisning.

Egengjøring, andregjøring og normalitet. Oslo: Akademika forlag.

Nicolaisen. Tove. 2014. «Rom og reiser i RLE. Innspill til pluralistisk og gjestfri RLE-didaktikk». I Prismet 1/65: 17-29. Oslo: IKO.

Nicolaisen, Tove. 2018. Hinduer. Oslo: Universitetsforlaget.psal, Jan. 2011a. «Muslimske monumentalbygg i norske bygater. Tre nybygde moskeer på Oslos østkant». I Hellige hus. Arkitektur og utsmykning i religiøst liv, red. Repstad og Tønnesen, 172-194. Oslo: Cappelen Damm Akademisk.

Opsal, Jan. 2011a. «Nye rom for gamle bønner. Bønnerom i nybygde moskeer i Oslo». I Hellige hus. Arkitektur og utsmykning $i$ religiøst liv, red. Repstad og Tønnesen, 195-210. Oslo: Cappelen Damm Akademisk.

Repstad, Kari og Inger Margrethe Tallaksen. 2014. Praktisk fagdidaktikk for religionsfagene. Oslo: Cappelen Damm.

Rogan, Bjarne. 2011. «Et faghistorisk etterord om materiell kultur og kulturens materialitet». I Materiell kultur \& kulturens materialitet, red. Naguib og Rogan, 313-381. Oslo: Novus forlag.

Rolland, Lars. 2016. Elevers oppfattelse av religiøs kunst $i$ undervisningen. En empirisk studie av responser fra vg3-elever på et hinduistisk kunstbilde, sett $i$ lys av bildeteori og religionsdidaktisk teori. Masteroppgave, Institutt for lærerutdanning og skoleforskning, Universitetet i Oslo. Tilgjengelig: http://urn.nb.no/ URN:NBN:no-55633 
Seland, Elin Heldaas. 2010. «Bilder på reise: Vår frue av Lourdes mellom fromhetskult og Kunst». I Talende bilder. Tekster om kunst og visuell kultur, red. Lien og Serck-Hansen, 180-197. Oslo: Spartacus forlag.

Soja, Edward W. 2011. Thirdspace. Journeys to Los Angeles and Other Real-andImagined Places. Malden: Blackwell Publishing.

Soja, Edward W. 2014. «Taking space personally». I The Spatial Turn. Interdisciplinary perspectives, red. Warf og Arias, 11-35. London: Routledge.

Stene, Nora. 2011. «Bilders kraft. Koptiske barns bruk av religiøse bilder. I Kairo og London». I Materiell kultur \& kulturens materialitet, red. Naguib og Rogan, 255-272. Oslo: Novus forlag.

Tuan, Yi-Fu. (1977) / 2011. Space and Place. The Perspective of Experience. Minneapolis: The University of Minnesota Press.

Winje, Geir. 2003. Valg og vurdering av kunstbilder i KRL. Tønsberg: Høgskolen i Vestfold.

Winje, Geir. 2012. Guddommelig skjønnhet. Kunst $i$ religionene. Oslo: Universitetsforlaget.

Winje, Geir. 2013. «Når kunst forkynner». I Religion og livssyn 3/13. 